Делова Людмила, кандидат социологических наук Адыгейский республиканский институт гуманитарных исследований

Имени Т. М. Керашева, г. Майкоп, Республика Адыгея, Россия

E-mail: ludmilaz29@mail.ru ORCID ID 0000-0003-4831-8387

\title{
ДЕМОГРАФИЧЕСКИЕ ПРОБЛЕМЫ В СОВРЕМЕННОМ МИРЕ
}

\author{
Delova Lyudmila, Candidate of Sociological Sciences \\ Adyghe Republican Institute for Humanitarian Studies named after TM Kerashev, \\ Maykop, Republic of Adygea, Russia \\ E-mail: ludmilaz29@mail.ru \\ ORCID ID 0000-0003-4831-8387
}

\section{DEMOGRAPHIC PROBLEMS IN THE MODERN WORLD}

Annotation: The article analyzes the current state of demographic processes in Russia and in the region - the Republic of Adygea. There is a natural decline in the population, a decrease in the number of marriages and an increase in the number of divorces. Population growth is achieved only through migration, which changes the ethnic picture of the region. The government has developed a "Concept of demographic policy until 2025", the purpose of which is the gradual stabilization of the population, measures are being taken to improve the demographic situation.

Keywords: demography, fertility, mortality, nuptiality, divorce rate, migration, natural decline, population policy.

Аннотация: В статье проанализировано современное состояние демографических проиессов в России и в регионе - Республике Адыгея. Отмечается естественная убыль населения, уменьшение количества заключённых браков и возрастание количества разводов. Рост населения обеспечивается лишь за счёт миграционных прочессов, что меняет этническую картину региона. Правительством разработана «Конщепџия демографической политики до 2025 года», иелью которой являются постепенная стабилизация численности населения, предпринимаются меры для улучшения демографической ситуации.

Ключевые слова: демография, рождаемость, смертность, брачность, разводимость, миграџия, естественная убыль, демографическая политика.

В течение нескольких десятилетий страны Европы переживают демографический кризис, который отрицательно сказывается или может сказаться на их развитии. Наиболее характерен он для Европы, где многие страны (Беларусь, Украина, Венгрия, Болгария, ФРГ и др.) имеют отрицательный естественный прирост. В число таких стран вошла и Россия. В целом для экономически развитых стран мира (средний показатель их естественного прироста 0,4\%o) характерен так называемый "рациональный" или "современный" тип воспроизводства населения, в основном соответствующий городскому образу и высокому уровню жизни их населения. Переход от характерной для старой России многодетной семьи к малодетной совершился в нашей стране еще в период существования Советского Союза. Но в 90-х гг. ХХ века прежде всего с возникновением глубокого социально-экономического кризиса начался настоящий "обвал" показателей естественного прироста населения. Начиная с девяностых годов XX века в России наблюдается депопуляция или естественная убыль населения. Депопуляция - уменьшение

Социологические науки демографические проблемы
Материалы Международной практической интернет-конференции «Актуальные Проблемы Науки» 
населения страны, региона в результате суженного воспроизводства, приводящего к его абсолютной убыли. Смертность превышает рождаемость, поколение родившихся меньше предыдущего, что вызывает серьёзную тревогу. Не происходит не только расширенного, но и простого воспроизводства населения. По прогнозам учёных на последующие годы, уровень рождаемости будет снижаться, показатели смертности увеличиваться, то есть масштабы естественной убыли значительно возрастут. Депопуляция населения в Российской Федерации в целом составляет серьёзную угрозу безопасности. Занимая 1-е место в мире по площади территории, Россия стремительно теряет свои позиции по демографическим показателям. Если в 1991 году Россия была на 6 месте по численности населения, в 2012 она перешла на 10-е место, по прогнозам, к 2050 г. Российская Федерация займёт 14 место в мире по численности населения. Численность постоянного населения Российской Федерации на 1 сентября 2018 г. составила 146,8 млн. человек. С начала года число жителей России сократилось на 84,7 тыс. человек, или на 0,06\% (в аналогичном периоде предыдущего года наблюдалось увеличение численности населения на 32,9 тыс. человек, или на 0,02\%). Миграционный прирост на 49,9\% компенсировал естественную убыль населения [1]. Отмечается уменьшение числа родившихся и числа умерших по сравнению с январем - сентябрем 2017 года. Так, в январе - сентябре 2017 г. естественная убыль населения составила 169,1 тыс. человек, за этот же период 2018 г. 104,5 тыс. человек. В целом по стране в январе - августе 2018 г. число умерших превысило число родившихся в 1,2 раза (в январе-августе 2017г. - в 1,1 раза). Не способствует улучшению демографической ситуации в стране и уменьшение количества заключённых браков (на 54,5 тыс. в 2018 г. по сравнению с аналогичным периодом 2017 г.) и возрастание числа разводов (на 1 тыс. в 2018 г. по сравнению с аналогичным периодом 2017 г.).

И в Республике Адыгея, входящей в состав Южного федерального округа, как и в большинстве регионов России, наблюдается естественная убыль населения. По данным Краснодарстата, в целом по республике в январе - сентябре 2018 года число умерших превысило число родившихся на 901 человека. Превышение числа умерших над числом родившихся составило 27,3\% (в 2017 году - 21,8\%). Вместе с тем за указанный период население Республики Адыгея увеличилось с начала года на 806 человек, что объясняется миграционным приростом. Не возрастает количество браков, заключённых на территории республики: по сравнению с тем же периодом 2017 г. их заключено на 82 меньше [2]. Миграционный прирост в Адыгее всегда являлся определяющим компонентом роста численности населения, а начиная с 1992 года, при фактической естественной убыли населения, миграция остается одним из основных источников сохранения демографического потенциала Адыгеи. Постепенно меняется и этническая ситуация в регионах. Так, в Республике Адыгея появились поселения курдов [3]. Миграция оказывает большое влияние на демографические процессы, что приводит к изменениям половозрастной и социальной структуры населения.

Опросы о репродуктивных установках, проведённые в различных регионах России, в том числе в Адыгее, показывают: основной причиной, не позволяющей людям реализовать своё желание иметь больше детей, являются экономические. Ответы респондентов, полученные в ходе социологических опросов, свидетельствуют: большинство жителей ориентировано на семью с двумя - тремя детьми. Основными препятствиями в реализации их репродуктивных установок являются социальноэкономические причины, в первую очередь крайне низкий уровень дохода, отсутствие социальных гарантий, неуверенность в завтрашнем дне. Следующая по значимости причина - это не устраивающие опрошенных жилищные условия [4; 5, с. 197-201; 6, с.

Социологические науки демографические проблемы
Материалы Международной практической интернет-конференции «Актуальные Проблемы Науки» 
133-135]. Рождение второго ребенка воспринимается как угроза, прежде всего повышению благосостояния семьи (29,3\% женщин и 26,8\% мужчин), получению более высоких личных доходов (29,5\% женщин и 20,3\% мужчин), интересному полноценному досугу (24,6\% женщин и 22,3\% мужчин). Кроме того, однодетные женщины сравнительно часто отмечали, что второй ребенок может помешать их профессиональному росту $(22,8 \%)[4]$.

По прогнозам, в ближайшие годы число проживающих в России женщин детородного возраста сократится на четверть и даже больше. Количество женщин репродуктивного возраста до 2032 или 2035 года уменьшится на 28\%. По данным Управления Федеральной службы государственной статистики по Краснодарскому краю и Республике Адыгея, в республике идет снижение численности женщин фертильного возраста (15-49 лет), в основном, из них женщин (20-29 лет), что отрицательно сказывается на рождаемости детей, особенно первенцев.

В 2007 г. в России была принята «Концепция демографической политики до 2025 года», целью которой являются постепенная стабилизация численности населения и формирование предпосылок последующего демографического роста [7] .

Думается, что меры, предпринимаемые государством: продление программы материнского капитала до 2022 года, выплаты на первого ребёнка, оплата доли ипотеки семьи государством - окажут существенное влияние на улучшение демографической ситуации в стране.

В этих условиях «перезагрузка» политики «демографического развития» России, о которой в конце 2017 г. объявил президент России Владимир Путин, сообщив о введении в 2018 году ежемесячных выплат семьям, в которых родился первый ребенок, приведёт к повышению рождаемости при условии снижения смертности населения.

Мерами, способствующими улучшению демографической ситуации в должны стать также:

Формирование репродуктивных установок. В активный репродуктивный возраст вступила молодёжь 1990-х годов рождения. Численность женщин репродуктивного возраста к 2020 г. будет меньше нынешней на 13\%. Часть из них будет представлять ставшую распространённой в 1990-е годы модель однодетности или «чайлдфри» - отказ от рождения детей.

Работа по культивированию и утверждению в общественном сознании ценности семьи, национальных традиций, в том числе среднедетности и многодетности.

Пропаганда здорового образа жизни, что будет способствовать отказу от вредных привычек, улучшению здоровья населения.

\section{ЛИТЕРАТУРА}

1. Сайт Федеральной службы государственной статистики России (Росстат) URL: http://www.gks.ru/wps/wcm/connect/rosstat_main/rosstat/ru/statistics/population/demography/ \# (дата обращения 12.11.2018).

2. Сайт статистики Управления Федеральной статистики по Краснодарскому краю и Республике Адыгея (Краснодарстат), (дата обращения 12.11.2018) URL: http://krsdstat.gks.ru/wps/wcm/connect/rosstat_ts/krsdstat/resources/3454de004f77903f9518d7 8250d62a05/Показатели+естественного+движения+населения.htm

3. Курды Адыгеи: монография / гл. ред. и руководитель научного проекта А.Н. Соколова; ред. А.Ю.Шадже, 3.А. Жаде. - Майкоп: Качество, 2015. - 204 с.

4. Сайт Федеральной службы государственной статистики России. Краткие итоги выборочного обследования «Семья и рождаемость». Электронный ресурс: URL: http://www.gks.ru/free_doc/ 2010/family.htm (дата обращения 7.11.2018г.).

Социологические науки демографические проблемы
Материалы Международной практической интернет-конференции «Актуальные Проблемы Науки» 
5. Калашаова Д.А., Делова Л.А. Репродуктивные установки жителей Республики Адыгея: социологический анализ/ Вестник Адыгейского государственного университета. Серия 1: Регионоведение: философия, история, социология, юриспруденция, политология, культурология. - 2017. - № 4 (209). .

6. Делова Л.А. Репродуктивное поведение: причины и особенности/ Вестник науки Адыгейского республиканского института гуманитарных исследований имени Т.М. Керашева. - 2018.- № 16 (40).

7. Концепция демографической политики Российской Федерации на период до 2025 года. [Электронный ресурс]. (дата обращения 10.11.2018 г.) - URL: http://base.garant.ru/191961/53f89421bbdaf741eb2d1ecc4ddb4c33/ 